\title{
Effects of copper and silver nanoparticles on growth of selected species of pathogenic and wood-decay fungi in vitro
}

\author{
by Marta Aleksandrowicz-Trzcińska, ${ }^{1}$ Adam Szaniawski, ${ }^{1}$ Jacek Olchowik, ${ }^{1}$ Stanisław Drozdowski2
}

\begin{abstract}
As research indicates a role for metal nanoparticles as fungicides, the work described here addresses the influence of copper nanoparticles (CuNPs) and silver nanoparticles (AgNPs) on the growth in vitro of pathogens causing damping-off as well as wood-decay fungi; i.e., Rhizoctonia solani (2 strains), Fusarium oxysporum, F. redolens and Phytophthora cactorum, along with Fistulina hepatica, Grifola frondosa, Meripilus giganteus and Sparassis crispa. Results indicate selective anti-fungal activity of the nanoparticles as applied at concentrations of 5, 15, 25 or $35 \mathrm{ppm}$. While neither nanoparticle affected $P$. cactorum or S. crispa, both inhibited growth in R. solani (strain 2), F. redolens and M. giganteus. R. solani (strain 1), F. oxysporum, F. hepatica and G. frondosa only showed sensitivity to higher concentrations of AgNPs, albeit with inhibitory impact on mycelial growth greater than with CuNPs. $R$. solani strains differed markedly in responses to both nanoparticles. Overall, the considerable toxicity of AgNPs and CuNPs to certain pathogens and wood-decay fungi indicates possible use in protecting nursery seedlings and safeguarding trees and wood, if with an awareness that certain fungi prove insensitive to both kinds of nanoparticle.
\end{abstract}

Keywords: anti-fungal activity, Rhizoctonia solani, Fusarium oxysporum, Fusarium redolens, Phytophthora cactorum, Fistulina hepatica, Grifola frondosa, Meripilus giganteus, Sparassis crispa

\begin{abstract}
RÉSUMÉ
Comme la recherche a démontré que les nanoparticules métalliques pouvaient être utilisées comme fongicides, les travaux décrits ici portent sur l'influence des nanoparticules de cuivre (CuNPs) et d'argent (AgNPs) sur la croissance in vitro d'agents pathogènes causant la fonte des semis et la carie du bois comme Rhizoctonia solani (2 souches), Fusarium oxysporum, F. redolens et Phytophthora cactorum, avec Fistulina hepatica, Grifola frondosa, Meripilus giganteus et Sparassis crispa. Les résultats laissent voir que lactivité antifongique se manifeste à des concentrations de 5, 15, 25 ou $35 \mathrm{ppm}$. Bien quaucune des deux sortes de nanoparticules n'ait eu d'effet sur P. cactorum ou S. crispa, les deux ont permis de limiter la croissance chez $R$. solani (souche 2), chez F. redolens et M. giganteus. $R$. solani (souche 1), F. oxysporum, F. hepatica et G. frondosa n’ont montré de la sensibilité qu'aux concentrations les plus élevées des AgNPs même si son effet d'inhibition sur la croissance mycelienne a été supérieur à celui des CuNPs. En somme, la très grande toxicité des AgNPs et des CuNPs pour certains agents pathogènes et champignons de carie laisse voir quon pourrait les utiliser pour protéger les semis en pépinière ainsi que pour la protection des arbres et du bois, tout noubliant pas que certains agents pathogènes nauront aucune sensibilité à ces deux types de nanoparticules.
\end{abstract}

Mots-clés : activité antifongique, Rhizoctonia solani, Fusarium oxysporum, Fusarium redolens, Phytophthora cactorum, Fistulina hepatica, Grifola frondosa, Meripilus giganteus, Sparassis crispa

\section{Introduction}

Nanomaterial is material with one dimension below $100 \mathrm{~nm}$, while this definition also encompasses the nanoparticles as atomic or molecular aggregates in which two dimensions are in the 1-100 nm range (Klaine et al. 2008). Such small dimensions set against relatively large surface areas ensure that nanoparticles have physical-chemical and biological properties markedly different from homogeneous materials of the same kind ( $\mathrm{Nel}$ et al. 2006). In turn, in line with origin, nanoparticles can be termed natural, incidental or engineered.

While the presence of natural nanoparticles in the environment (as moon-dust or volcanic ash, for example) reflects processes ongoing on Earth historically and today, the incidental nanoparticles are various kinds of waste or other anthropogenic creations generated as an unsought side effect of industrial processes (Monica and Cremoni 2009). That leaves the engineered nanoparticles, synthesised as various chemical or physical processes, harnessed (Masarovičová and Králová 2013) or produced with the use of biological material via bacterial, algal, fungal or vascular plant "green synthesis" (Mohanpuria et al. 2008).

The unique electronic, optical, mechanical, magnetic and chemical properties of nanoparticles (Masarovičová and Králová 2013) are such that they have a wide range of applications in medicine, pharmacy, cosmetology, electronics, the

\footnotetext{
${ }^{1}$ Department of Forest Protection and Ecology, Faculty of Forestry, Warsaw University of Life Sciences, Nowoursynowska 159, 02-776 Warsaw, Poland; *e-mail: marta_aleksandrowicz_trzcinska@sggw.pl

${ }^{2}$ Department of Silviculture, Faculty of Forestry, Warsaw University of Life Sciences, Warsaw, Poland
} 
building industry, jewellery-making, photography and agriculture (Monica and Cremoni 2009) and even forestry (McCrank 2009). Among other things, many studies point to their antiviral, antibacterial and antifungal properties (Marambio-Jones and Hoek 2010).

Damping-off is a fungal disease capable of generating major losses in forest nurseries. It is caused by pathogens belonging to a range of different systematic groups, including Rhizoctonia solani J.G. Kühn, Fusarium oxysporum Schltdl. and other Fusarium species, and Phytophthora cactorum (Lebert \& Cohn) J. Schröt. (Lazreg et al. 2014). This heterogeneity of origin combines with the emergence of resistance to fungicides to make this disease very hard to combat (Goffeau 2008). However, work done hitherto in vitro made clear certain antifungal properties of silver nanoparticles in relation to a range of pathogenic species, including those responsible for damping off. Efficacy of nanoparticles has inter alia been revealed in relation to Bipolaris sorokiniana Shoemaker and Magnaporthe grisea (T.T. Hebert) M.E. Barr (Jo et al. 2009), the oak wilt pathogen Raffaelea sp. (Kim et al. 2009), Fusarium culmorum (Wm.G. Sm.) Sacc. (Kasprowicz et al. 2010), Sclerotinia sclerotiorum (Lib.) de Bary, S. minor Jagger and R. solani (Min et al. 2009), and Colletotrichum gloeosporioides (Penz.) Penz. \& Sacc. (Aguilar-Mèndez et al. 2011). Furthermore, there are some pathogens against which the efficacy of silver nanoparticles has already been tested in vivo (Jo et al. 2009), although some of this work suggests that fungicide applications have a comparatively greater impact (Mahdizadeh et al. 2015).

The use of fungicides to help preserve old (often "Monument of Nature-Status") trees by curtailing the spread of fungal rots is something that remains poorly known. Thus far trials have involved the application of systemic fungicides like Topsin and Falcon (Zarzyński 2003). In turn, work using Copper-Carbon Core-Shel Nanoparticles was able to demonstrate their effectiveness in protecting trees from blue stain fungus Ophiostoma minus (Hedgc.) Syd. \& P. Syd., as well as the white-rot fungus Trametes versicolor (L.) Lloyd. This work did not indicate any phytotoxicity of these Copper-Carbon Core-Shel Nanoparticles (Qi et al. 2012). Beyond that, Heiden et al. (2005) showed that, by using nanoparticles to protect wood, it is possible to avoid problems encountered previously with such flaws of preparations used as an excessive propensity to wash off and a tendency to produce toxicity in the environment.

Modern forestry in the EU and in Poland is in constant search of environment-friendly technological solutions. These relate to both nursery production and the tending and protection of trees and wood. Given that metal nanoparticles are not very toxic to either people or animals (and certainly less so than synthetic fungicides), there is considerable interest in them from this point of view, but also because the multiple modes of action would seem to imply difficulties for fungi in developing resistance (Jo et al. 2009).

Such considerations are behind the work described in this paper, which sought to assess nanoparticles of silver (AgNPs) and copper (CuNPs) deployed in vitro against the fungi and Oomycetes causing damping-off of seedlings and the decay of wood.

\section{Materials and Methods \\ Fungal isolates}

The research was carried out on four species giving rise to damping-off of seedlings (i.e., three kinds of fungi (four strains) + one species of oomycete; table 1), as well as four species of fungi producing wood decay (otherwise "heart-rot fungi"; table 2), first and foremost in old trees of large dimensions. The tested species that are causative agents of dampingoff were Rhizoctonia solani J.G. Kühn strains 5648.01 (1) and 1195.00 (2), Fusarium oxysporum Schltdl. strain 103 and Fusarium redolens Wollenw. strain 229, as well as Phytophthora cactorum (Lebert \& Cohn) J. Schröt. strain 351.1. In turn, the fungi responsible for wood decay were Fistulina hepatica (Schaeff.) With., Grifola frondosa (Dicks.) Gray, Meripilus giganteus (Pers.) P. Karst., and Sparassis crispa (Wulfen) Fr. These species are characterised in Tables 1 and 2. The names of the fungi and their systematic positions are given after the MycoBank base (www.mycobank.org). F. redolens was obtained from the Freie Universität Berlin, Institute of Biology, while remaining strains of the species responsible for damping-off were obtained from the Department of Forest Pathology, Mycology and Tree Physiology at the Faculty of Forestry of the Kraków-based University of Agriculture. The wood-decay fungi in turn derive from the culture collection of the Department of Forest Protection and Ecology at the Faculty of Forestry of Warsaw University of Life Sciences.

\section{Nanoparticles}

The two types of metal nanoparticles chosen were silver (AgNPs) and copper (CuNPs). Samples of commercially available solutions of silver and copper nanoparticles were purchased from Nano-Koloid (Nano Koloid Sp. z o. o), as a licensee of Nano Technologies Group, Inc. (USA). As the producer noted, these are generated in a physical process, consist of around 100 atoms and are suspended in demineralised water. The concentration of nanoparticles in the commercially-available product is $50 \mathrm{ppm}$.

\section{In vitro assay}

The experiment was conducted using Petri dishes $9-\mathrm{cm}$ in diameter. Fungi were cultured on three types of media, i.e., potato dextrose agar, PDA (R. solani, F. oxysporum, $F$. redolens), V8 multi-vegetable agar medium (P. cactorum), and malt extract agar MEA (wood-decay fungi). Nanoparticles were added to the medium at concentrations of 5, 15, 25 or $35 \mathrm{ppm}$. Control dishes contained only PDA, V8 or MEA. Each trial combination (of strain of fungus and concentration of nanoparticles) was the subject of 10 replicates (i.e., 10 Petri dishes). The inoculum took the form of discs of 2week-old fungal culture of $3 \mathrm{~mm}$ diameter. The fungi were incubated in the dark at $22{ }^{\circ} \mathrm{C}$. Measurements of mycelial diameter were made after seven days for species causing damping-off of seedlings and those responsible for the decomposition of wood. An exception was S. crispa, for which the measurement was made after 28 days. The time of measurement was related to the rate of growth of the mycelium, in that this was done at the time the growing patch of mycelium reached the edge of the Petri dish. The "crosswise" reading-off of two measurements was done on the base of each dish, to an accuracy of 1-mm. 
The results were used to calculate an index of inhibition or stimulation with the formula:

$$
\mathrm{I} / \mathrm{SI}=(\mathrm{DT}-\mathrm{DC}) / \mathrm{DC} \times 100 \%
$$

Where I/SI is the index of the inhibition/stimulation (\%), DT the diameter of the fungal colony on the test plate and DC the diameter of the fungal colony on the control plate. This formula for the index is such that a negative value indicates inhibition of fungal growth, while a positive one relates to stimulation.

\section{Statistical analysis}

In advance of more far-reaching statistical analysis, the Shapiro-Wilk W test was used to check for conformity of data on the feature studied (i.e., colony diameter) with a normal distribution. A Levene Test was also used to compare for uniformity of variance. Given that the distribution of the variable tested was not found to differ significantly from the normal distribution, while the variance characterising the compared research variants was uniform, there was justification of the use of analysis of variance of data relating to type of nanoparticle (of $\mathrm{Ag}$ or $\mathrm{Cu}$ ), as well as the nested variable of nanoparticle concentration ( 0 in the case of the control, or $5,15,25$ and $35 \mathrm{ppm}$ ). A post-hoc Tukey HSD test was applied.

Calculations involved the general linear model (GLM) in the Statistica package (StatSoft Inc., Tulsa, OK, USA), i.e.,

$$
Y_{i j k}=\mu+\alpha_{i}+\left(\beta_{j}\right) \alpha_{i}+\varepsilon_{i j k} \text {, }
$$

Where $\mu$ is the overall mean, $\alpha_{i}$ the influence of nanoparticles $(i=1-2), \beta_{j}$ a nested variable determining the influence of nanoparticle concentration (where $m=1-5$ ), and $\varepsilon_{i j k}$ a random component

\section{Results}

Our research pointed to a significant influence on the growth of cultures of the species of fungus tested due to both the type of nanoparticle $(\mathrm{p}<0.0001)$ and the concentration at which it was present $(\mathrm{p}<0.0001)$. AgNPs limited the radial growth of mycelium significantly at concentrations of 15, 25 and 35 ppm, while CuNPs only exerted an effect at a concentration of $25 \mathrm{ppm}$. Stronger inhibition due to AgNPs was observed (Fig. 1).

Different species of both pathogenic and wood-decay fungi are characterised by diverse sensitivities to the experimental use of nanoparticles (Fig. 2). Among the pathogens, $P$. cactorum showed a complete lack of sensitivity to the action of either type of nanoparticle, with the lowest concentration of AgNPs actually seen to stimulate mycelial growth. In contrast, the species with growth most constrained was $R$. solani (2). However, the other strain of $R$. solani (1) was only sensitive to AgNPs at the highest concentration tested. Mycelial growth in F. redolens was in turn inhibited by both types of nanoparticle at all of the applied concentrations with the exception of AgNPs at the lowest dosage. F. oxysporum was characterised by both resistance and sensitivity to the nanoparticles, depending on both type and concentration (Tables 3 and 4). This species was the only one to secrete pigment more intensively into the medium.

Among the fungi responsible for wood-decay, S. crispa emerged as insensitive to either type of nanoparticle at any of the concentrations. The most sensitive species was $M$. giganteus, whose growth was limited significantly as compared with the control by all concentrations of both types of nanoparticle, other than by CuNPs at their lowest concentration. Growth of the two remaining species, F. hepatica and G. frondosa, was held back markedly by AgNPs at concentrations of 15, 25 or 35 ppm (Tables 5 and 6).

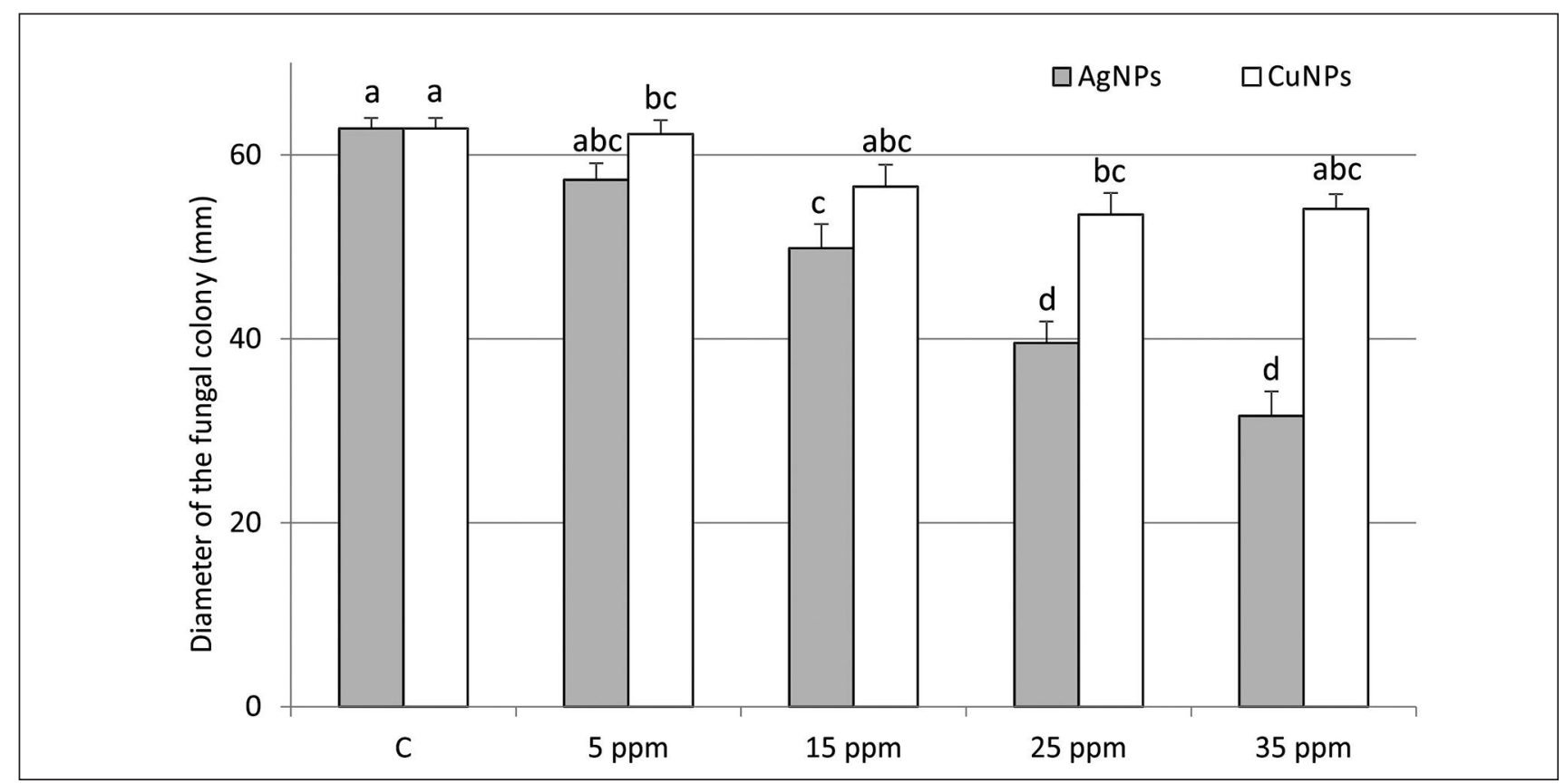

Fig. 1. The impact of the different concentrations of nanoparticles of silver (AgNPs) and copper (CuNPs) on the diameters of fungal colonies (of all tested isolates). Letters indicate significant differences obtained using the Tukey HSD test, $P \leq 0.05$. 

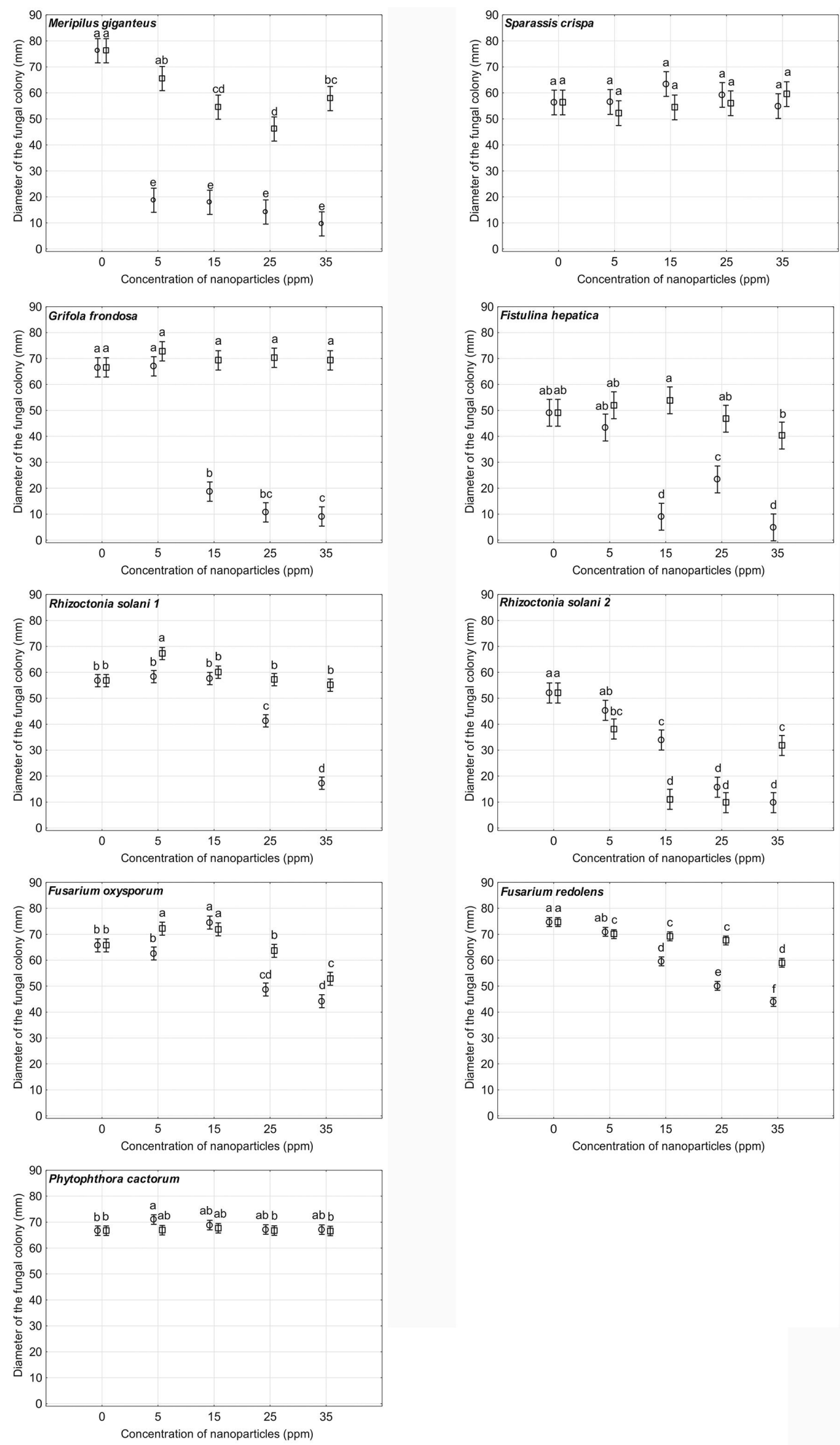

Fig. 2. The impact of the different concentrations of nanoparticles of silver (AgNPs - $\bigcirc$ ) and copper (CuNPs - $\square$ ) on the diameters of fungal colonies. Letters indicate significant differences obtained using the Tukey HSD test, $P \leq 0.05$. 
Table 1. Classification of the studied pathogenic fungi and Oomycetes

\begin{tabular}{lll}
\hline Species & Strain & Classification \\
\hline Rhizoctonia solani & $5648.01,1195.00$ & Fungi, Basidiomycota, Agaricomycotina, Agaricomycetes, Cantharellales, Ceratobasidiaceae \\
Fusarium oxysporum & 103 & $\begin{array}{l}\text { Fungi, Ascomycota, Pezizomycotina, Sordariomycetes, Hypocreomycetidae, Hypocreales, } \\
\text { Nectriaceae }\end{array}$ \\
Fusarium redolens & 229 & $\begin{array}{l}\text { Fungi, Ascomycota, Pezizomycotina, Sordariomycetes, Hypocreomycetidae, Hypocreales, } \\
\text { Nectriaceae }\end{array}$ \\
Phytophthora cactorum & 351.1 & Chromista, Oomycota, Oomycetes, Peronosporales \\
\hline
\end{tabular}

Table 2. Classification of the studied wood-decay fungi and types of decay associated with them

\begin{tabular}{lll}
\hline Species & Classification & Type of decay \\
\hline Fistulina hepatica & $\begin{array}{l}\text { Fungi, Basidiomycota, Agaricomycotina, Agaricomycetes, } \\
\text { Agaricomycetidae, Agaricales, Fistulinaceae, }\end{array}$ & White rot, stem decay of deciduous trees \\
Grifola frondosa & $\begin{array}{l}\text { Fungi, Basidiomycota, Agaricomycotina, Agaricomycetes, } \\
\text { Polyporales, Fomitopsidaceae, }\end{array}$ & $\begin{array}{l}\text { White pocket rot, root and butt decay of deciduous } \\
\text { trees (occasionally coniferous) }\end{array}$ \\
Meripilus giganteus & $\begin{array}{l}\text { Fungi, Basidiomycota, Agaricomycotina, Agaricomycetes, } \\
\text { Polyporales, Meripilaceae, }\end{array}$ & White rot, root and butt decay of deciduous trees \\
Sparassis crispa & $\begin{array}{l}\text { Fungi, Basidiomycota, Agaricomycotina, Agaricomycetes, } \\
\text { Polyporales, Sparassidaceae }\end{array}$ & Brown rot, root and butt decay of coniferous trees \\
\hline
\end{tabular}

Table 3. Index of percentage inhibition (minus) or stimulation (plus) of growth in tested pathogenic fungi and Oomycetes in relation to applied concentrations of nanoparticles of silver $(\mathrm{Ag})$ and copper $(\mathrm{Cu})$ [5, 15, 25 and 35 ppm). Standard error in bracket

\begin{tabular}{lccccc}
\hline $\begin{array}{l}\text { Nanoparticle/ } \\
\text { concentration }\end{array}$ & $\begin{array}{c}\text { Rhizoctonia } \\
\text { solani (1) }\end{array}$ & $\begin{array}{c}\text { Rhizoctonia } \\
\text { solani (2) }\end{array}$ & $\begin{array}{c}\text { Fusarium } \\
\text { oxysporum }\end{array}$ & $\begin{array}{c}\text { Fusarium } \\
\text { redolens }\end{array}$ & $\begin{array}{c}\text { Phytophthora } \\
\text { cactorum }\end{array}$ \\
\hline Ag 5 & $3.1(2.66)$ & $-12.5(4.34)$ & $-4.3(3.43)$ & $-5.0(1.45)$ & $6.7(1.55)^{*}$ \\
Ag 15 & $1.9(3.60)$ & $-34.9(2.44)^{*}$ & $13.7(1.84)^{\star}$ & $-20.2(1.60)^{*}$ & $3.5(2.11)$ \\
Ag 25 & $-27.0(2.72)^{*}$ & $-69.8(1.25)^{*}$ & $-25.6(2.84)^{*}$ & $-32.9(1.46)^{*}$ & $1.0(3.06)$ \\
Ag 35 & $-69.4(1.17)^{*}$ & $-81.3(1.14)^{*}$ & $-32.6(1.25)^{*}$ & $-41.2(1.06)^{*}$ & $0.9(1.95)$ \\
Cu 5 & $19.0(2.87)^{*}$ & $-26.4(5.28)^{*}$ & $10.2(3.30)^{*}$ & $-6,2(1.21)^{*}$ & $0.5(1.63)$ \\
Cu 15 & $6.5(3.91)$ & $-78.8(1.03)^{*}$ & $9.7(2.36)^{*}$ & $-7,3(1.28)^{*}$ & $1.6(1.61)$ \\
Cu 25 & $0.8(1.50)$ & $-81.2(0.87)^{*}$ & $-3.0(2.39)$ & $-9.5(1.48)^{*}$ & $0.3(2.06)$ \\
Cu 35 & $-2.7(2.46)$ & $-37.9(9.85)^{*}$ & $-19.0(3.89)^{*}$ & $-21.0(1.21)^{*}$ & $0.2(3.09)$ \\
\hline
\end{tabular}

*differences in colony diameters significant (at $\mathrm{P} \leq 0.05)$ in relation to the control, as obtained using the Tukey HSD test

\section{Discussion}

Our work points to differentiated impacts of AgNPs and CuNPs on the growth of both pathogenic and wood-decay fungi. In fact, it was possible to identify three groups of species where sensitivity or vulnerability were concerned. A first group - comprising P. cactorum and S. crispa - is species entirely insensitive to the action of the particles, while the second includes $R$. solani (2), F. redolens and $M$. giganteus as species sensitive or very sensitive to both types. The third and largest group, R. solani (1), F. oxysporum, F. hepatica and G. frondosa were only sensitive to AgNPs at higher concentrations. The differentiated levels of sensitivity of the fungi and Oomycetes to the action of nanoparticles may possibly be linked to the toxicity mechanisms involved or to the capacity of fungi to mobilise defensive reactions linked with resistance or detoxification mechanisms (Gadd 2007).

The mechanisms underpinning the antimicrobial action of nanoparticles have not yet been elucidated fully, although several explanatory theories exist in the case of bacteria. Nanoparticles may act to ensure the appearance of reactive oxygen species (ROS) in cells, with consequent damage done to proteins, lipids and nucleic acids (Nel et al. 2006). Nanoparticles are also known to curtail the capacity of DNA to replicate. A further mechanism involves linkages between metal nanoparticles and thiol (-SH) groups of proteins, with the effect being deactivation of the latter (Alghuthaymi et al. 2015). Nanoparticles may also adhere to cell surfaces, compromising membrane integrity and functioning (Klaine et al. 
Table 4. ANOVA results for the statistical significance of the effect of nanoparticles and their concentrations on colony diameters among tested pathogenic fungi and Oomycetes

\begin{tabular}{|c|c|c|c|c|c|c|c|c|c|c|c|}
\hline \multirow{2}{*}{$\begin{array}{l}\text { Source of } \\
\text { variation }\end{array}$} & \multirow[b]{2}{*}{ df } & \multicolumn{2}{|c|}{$\begin{array}{l}\text { Rhizoctonia } \\
\text { solani (1) }\end{array}$} & \multicolumn{2}{|c|}{$\begin{array}{l}\text { Rhizoctonia } \\
\text { solani }(2)\end{array}$} & \multicolumn{2}{|c|}{$\begin{array}{l}\text { Fusarium } \\
\text { oxysporum }\end{array}$} & \multicolumn{2}{|c|}{$\begin{array}{l}\text { Fusarium } \\
\text { redolens }\end{array}$} & \multicolumn{2}{|c|}{$\begin{array}{l}\text { Phytophthora } \\
\text { cactorum }\end{array}$} \\
\hline & & $\mathbf{F}$ & $\mathbf{P}$ & $\mathbf{F}$ & $\mathbf{P}$ & $\mathbf{F}$ & $\mathbf{P}$ & $\mathbf{F}$ & $\mathbf{P}$ & F & $\mathbf{P}$ \\
\hline Nanoparticles & 1 & 297.87 & $<0.0001$ & 5.13 & 0.0260 & 930.20 & $<0.0001$ & 233.10 & $<0.0001$ & 4.51 & 0.0364 \\
\hline Concentrations & 8 & 118.31 & $<0.0001$ & 87.47 & $<0.0001$ & 1089.60 & $<0.0001$ & 140.57 & $<0.0001$ & 1.98 & 0.0573 \\
\hline
\end{tabular}

Bolded values indicate differences significant at the $\mathrm{P} \leq 0.05$ level

Table 5. Index of percentage inhibition (minus) or stimulation (plus) of growth in tested wood-decay fungi in relation to the applied concentrations of nanoparticles of silver ( $\mathrm{Ag})$ and copper (Cu) $(5,15,25$ and $35 \mathrm{ppm})$. Standard error in bracket

\begin{tabular}{|c|c|c|c|c|}
\hline $\begin{array}{l}\text { Nanoparticle/ } \\
\text { concentration }\end{array}$ & $\begin{array}{r}\text { Fistulina } \\
\text { hepatica }\end{array}$ & $\begin{array}{c}\text { Grifola } \\
\text { frondosa }\end{array}$ & $\begin{array}{l}\text { Meripilus } \\
\text { giganteus }\end{array}$ & $\begin{array}{c}\text { Sparassis } \\
\text { crispa }\end{array}$ \\
\hline $\operatorname{Ag} 5$ & $-11.0(4.57)$ & $0.7(3.02)$ & $-75.5(3.16)^{\star}$ & $0.8(3.66)$ \\
\hline Ag 15 & $-80.8(7.96)^{*}$ & $-72.0(1.83)^{\star}$ & $-76.5(1.61)^{\star}$ & $13.1(3.37)$ \\
\hline $\operatorname{Ag} 25$ & $-51.4(4.23)^{\star}$ & $-84.0(2.26)^{\star}$ & $-81.4(1.21)^{\star}$ & $5.6(3.49)$ \\
\hline Ag 35 & $-89.9(1.75)^{*}$ & $-86.5(5.56)^{*}$ & $-87.4(0.91)^{\star}$ & $-1.5(7.67)$ \\
\hline $\mathrm{Cu} 5$ & $8.7(10.26)$ & $9.5(2.51)$ & $-14.1(1.60)$ & $-6.9(5.84)$ \\
\hline $\mathrm{Cu} 15$ & $12.6(9.68)$ & $4.2(1.94)$ & $-28.4(2.89)^{\star}$ & $-2.8(4.44)$ \\
\hline $\mathrm{Cu} 25$ & $-2.2(8.54)$ & $5.6(1.72)$ & $-39.6(2.82)^{\star}$ & $-0.5(6.38)$ \\
\hline $\mathrm{Cu} 35$ & $-15.6(8.95)$ & $4.1(4.06)$ & $-23.7(7.97)^{\star}$ & $6.9(8.73)$ \\
\hline
\end{tabular}

*differences in colony diameters significant (at $\mathrm{P} \leq 0.05$ ) in relation to the control, as obtained using the Tukey HSD test

Table 6. ANOVA results for statistical significance of the effect of nanoparticles and their concentrations on colony diameters among tested wood-decay fungi

\begin{tabular}{|c|c|c|c|c|c|c|c|c|c|}
\hline \multirow[b]{2}{*}{ Source of variation } & \multirow[b]{2}{*}{ df } & \multicolumn{2}{|c|}{ Fistulina hepatica } & \multicolumn{2}{|c|}{ Grifola frondosa } & \multicolumn{2}{|c|}{ Meripilus giganteus } & \multicolumn{2}{|c|}{ Sparassis crispa } \\
\hline & & $\mathbf{F}$ & $\mathbf{P}$ & F & $\mathbf{P}$ & $\mathbf{F}$ & $\mathbf{P}$ & $\mathbf{F}$ & $\mathbf{P}$ \\
\hline Nanoparticles & 1 & 192.13 & $<0.0001$ & 913.94 & $<0.0001$ & 505.77 & $<0.0001$ & 2.55 & 0.1179 \\
\hline Concentrations & 8 & 32.17 & $<0.0001$ & 131.28 & $<0.0001$ & 84.18 & $<0.0001$ & 1.67 & 0.1355 \\
\hline
\end{tabular}

Bolded values indicate differences significant at the $\mathrm{P} \leq 0.05$ level

2008). Moreover, these mechanisms are considered to operate simultaneously, rather than purely in isolation of one another, i.e., via multiple modes of action (Alghuthaymi et al. 2015).

The potential or actual antifungal mechanisms of nanoparticles are far less known. However, He et al. (2011) considered that these differ from the antibacterial properties demonstrated. Kim et al. (2009) found that the growth of the pathogenic ascomycete Raffaelea spp. causing oak dieback in Korea was impaired due to damage AgNPs do to cell walls. He et al. (2011) in turn reported an accumulation of nucleic acid and carbohydrates in mycelial cells, albeit with protein and lipid contents left unchanged. These authors suggested that the increased content of carbohydrate and nucleic acid might be a reaction to stress on the part of fungal cells, with the former change in particular suggesting mobilisation of a protective reaction against nanoparticles.

Kim et al. (2012) further showed 14.4-84.0\% inhibition of mycelial growth in F. oxysporum, depending on type of growth media and concentration of AgNPs applied. In the context of our study, the same species emerged as one of the least sensitive of the strains studied, with low concentrations of the two types of nanoparticle even seen to stimulate mycelial growth. A similar stimulation of growth in the mould Mortierella alpine Peyronel was attributed to added AgNPs by Ogar et al. (2015). With the two species mentioned previously, there was a change of colour of the medium associated with the mycelial synthesis and liberation of pigments. The presence of nanoparticles clearly stimulated the production and extraction of extracellular chelating agents such as pigments. This could be a mechanism by which to immobilise toxic $\mathrm{Ag}^{+}$via extracellular chelation, chemical binding and finally, the protection of hyphae from the entry of ions into the mycelium (Ogar et al. 2015).

Gadd (2007) points to a high level of tolerance of Fusarium fungi to the action of heavy metals. Species of this genus tend to be isolated in large numbers from soils contaminated by 
these metals. However, our results offer only partial confirmation of this, given that, of the two Fusarium species studied, only $F$. oxysporum emerged with limited sensitivity, in particular to CuNPs. The second species, F. redolens, proved most sensitive to the action of both types of nanoparticles.

Fungi may be characterised by marked differences between strains when it comes to the action of different factors, including fungicides (Aleksandrowicz-Trzcińska and Grzywacz 1997). Such differences in sensitivity to nanoparticles were shown for the two strains of $R$. solani studied. Strain 5648.01 (1) emerged as insensitive to CuNPs as well as to the 5 and 15 ppm concentrations of AgNPs, while strain 1195.00 (2) displayed one of the most marked sensitivities of any of the species, and to the nanoparticles of both types. Mahdizadeh et al. (2015) found similar statistically significant differences in levels of inhibition induced in mycelia of the two R. solani strains by AgNPs.

A lack of sensitivity to all concentrations of the two types of nanoparticles was displayed by P. cactorum, the only trialled member of the Oomycota (within Kingdom Chromista), and characterised by the presence of cellulose in the cell walls. The remaining species within the phyla Ascomycota or Basidiomycota have chitin in their cell walls. However, it would not appear to be cell-wall chemical composition that determines insensitivity, since similar results were obtained for S. crispa (of the Basidiomycota). Moreover, work by Mahdizadeh et al. (2015) showed considerable vulnerability to even low concentrations of AgNPs on the part of Pythium aphanidermatum (Edson) Fitzp., which is also among the Oomycota.

Unlike the pathogens resulting in damping-off of seedlings, the fungi giving rise to wood decay had not been studied previously from the point of view of their sensitivity to nanoparticles. However, our work shows that they resemble the studied pathogens in displaying varying degrees of sensitivity to the two types of nanoparticles. The only species not vulnerable to either of these is S.crispa - the species growing slowest on the medium and differing from the other species of fungus in being responsible for brown rot in coniferous species. However, these particular features would not seem to have relevance to insensitivity to nanoparticles, given that the most sensitive species, $M$. giganteus, does not differ from $F$. hepatica in relevant respects, even though the latter was more resistant to nanoparticle activity. Both species produce white rot in broadleaved trees.

Unlike the work of other authors, our studies point to selective antifungal activity in both AgNPs and CuNPs. However, AgNPs proved more powerful than CuNPs, especially where higher concentrations ( 25 and $35 \mathrm{ppm}$ ) were concerned. Differences in the results of research pursued by different authors may reflect the way that the biological impact of nanoparticles depends on size, chemical composition, surface structure, solubility, shape and aggregation ( $\mathrm{Nel}$ et al. 2006). The different results obtained by different authors may also reflect the media used (Kaur et al. 2016).

The two metals studied have been known for centuries for their antimicrobial properties (Clement and Jarrett 1994), Copper compounds have been and are still used as fungicides in both plant protection (Franich 1988) and the safeguarding of timber (Freeman and McIntyre 2008). The high toxicity of $\mathrm{AgNPs}$ and CuNPs to certain pathogens causing damping-off or wood decay points to the possibility of both being used as alternatives to fungicides in the protection of seedlings at forest nurseries and the preservation of monumental trees. Naturally, the demonstrable insensitivity of some species of fungi to both types of nanoparticles needs to be borne in mind, however.

As our work considered two types of metal nanoparticle, and as many authors consider nanotechnology to offer green and eco-friendly alternatives in plant disease management (Alghuthaymi et al. 2015), future research should be expanded to include other types of nanomaterials such as nanoscale metal oxides and carbon nanotubes.

\section{Conclusions}

While both AgNPs and CuNPs are shown to have variable antifungal activity in respect of both the pathogens producing damping-off of seedlings and fungi responsible for wood decay, their benefits are sufficient to imply usefulness as alternatives to chemical methods and measures, where sensitive species are concerned. Given this conclusion, future studies ought to extend to a wider range of nanomaterials.

\section{Acknowledgments}

The authors thank Prof. Hanna Stępniewska, Dr Jacek Piętka and Dr Carlos Aguilar for sharing the fungal cultures used in this study. This work was supported by the Rector of Warsaw University of Life Sciences (SGGW) within the framework of research projects 505-10-030400-L00373-99 and 505-10030400-L00374-99. The editorial help of James R.A. Richards, $\mathrm{PhD}$ is also gratefully acknowledged.

\section{References}

Aleksandrowicz-Trzcińska, M. and A. Grzywacz. 1997. The effect of fungicides used in the protection of forest tree seedlings on the growth of ectomycorrhizal fungi. Acta Mycologica 32 (2): 315-322.

Alghuthaymi, M.A., H. Almoammar, M. Rai, E. Said-Galiev and K.A. Abd-Elsalam 2015. Myconanoparticles: synthesis and their role in phytopathogen management. Biotechnol. Biotechnol. Equip. 29(2): 221-236. doi: 10.1080/13102818.2015.1008194.

Aguilar-Mèndez, M.A., E.S. Martín-Martínez, L. Ortega-Arroyo, G. Cobián-Portillo and E. Sánchez-Espíndola. 2011. Synthesis and characterization of silver nanoparticles: effect on phytopathogen Colletotrichum gloesporioides. J. Nanopart. Res. 13: 2525-2532. doi: 10.1007/s11051-010-0145-6.

Clement, J.L. and P.S. Jarrett. 1994. Antibacterial silver. Met. Based Drugs 1(5-6): 467-482. doi: 10.11.55/MBD.1994.467.

Franich R.A. 1988. Chemistry of weathering and solubilisation of copper fungicide and the effect of copper on germination, growth, metabolism, and reproduction of Dothistroma pini. N. Z. J. For. Sci. 18(3): 318-328.

Freeman M.H. and C.R. McIntyre. 2008. A comprehensive review of cooper-based wood preservatives with a focus on new micronized or dispersed copper systems. Forest Prod. J. 58(11):6-27.

Gadd, G.M. 2007. Geomycology: biogeochemical transformations of rock, minerals, metals and radionuclides by fungi, bioweathering and bioremediation. Mycol. Res. 111: 3-49. doi: 10.1016/ j.mycres.2006.12.001.

Goffeau, A. 2008. Drug resistance: The fight against fungi. Nature, 452: 541-542. doi: 10.1038/452541a.

He, L., Y. Liu, A. Mustapha and M. Lin. 2011. Antifungal activity of zinc oxide nanoparticles against Botrytis cinerea and Penicillium expansum. Microbiol. Res. 166: 207-215. doi: 10.1016/j.micres. 2010.03.003.

Heiden, P., L. Matuana and B. Dawson-Andoh. 2005. Nanotechnology: A novel approach to prevent biocide leaching. 
https://archive.epa.gov/ncer/publications/web/pdf/heiden.pdf (accessed 2 January 2017).

Jo, Y.-K., B.H. Kim and G. Jung. 2009. Antifungal activity of silver ions and nanoparticles on phytopathogenic fungi. Plant Dis. 93: 1037-1043. doi:10.1094/PDIS-93-10-1037.

Kasprowicz, M.J., M. Kozioł and A. Gorczyca. 2010. The effect of silver nanoparticles on phytopathogenic spores of Fusarium culmorum. Can. J. Microbiol. 56: 247-253. doi: 10.1139/W10-012.

Kaur, A., J. Kaur, A. Kalia and N. Singh. 2016. Effect of media composition on extent of antimycotic activity of silver nanoparticles against plant pathogenic fungus Fusarium moniliforme. Pl. Dis. Res. 31(1): 1-5.

Kim, S.W., J.H. Jung, K. Lamsal, Y.S. Kim, J.S. Min and Y.S. Lee. 2012. Antifungal effects of silver nanoparticles (AgNPs) against various plant pathogenic fungi. Mycobiology 40(1):53-58. doi: 10.5941/MYCO.2012.40.1.053.

Kim, S.W., K.S. Kim, K. Lamsal, Y.-J. Kim, S.B. Kim, M. Jung, S.J. Sim, H.S. Kim, S.-J. Chang, J.K. Kim and Y.S. Lee. 2009. An in vitro study of the antifungal effect of silver nanoparticles on oak wilt pathogen Raffaelea sp. J. Microbiol. Biotechnol. 19(8): 760-764. doi: 10.4014/jmb.0812.649.

Klaine, S.J., P.J.J. Alvarez, G.E. Batley, T.F. Fernandes, R.D. Handy, D.Y. Lyon, S. Mahendra, M.J. McLaughlin and J.R. Lead. 2008. Nanomaterials in the environment: behavior, fate, bioavailability, and effects. Environ. Toxicol. Chem. 27(9): 1825-1851.

Lazreg, F., L. Belabid, J. Sanchez, E. Gallego and B. Bayaa. 2014. Pathogenicity of Fusarium spp. associated with diseases of Aleppopine seedlings in Algerian forest nurseries. J. For. Sci. 60(3):115-120. Mahdizadeh, V., N. Safaie and F. Khelghatibana. 2015. Evaluation of antifungal activity of sliver nanoparticles against some phytopathogenic fungi and Trichoderma harzianum. J. Crop Prot. 4(3): 291300.

Marambio-Jones, C. and E.M.V. Hoek. 2010. A revive of the antibacterial effects of silver nanomaterials and potential implications for human health. J. Nanopart. Res. 12: 1531-1551. doi: 10.1007/ s11051-010-9900-y.
Masarovičová, E. and K. Králová. 2013. Metal nanoparticles and plants. Ecol. Chem. Eng. S 20(1): 9-22. doi: 10.2478/eces-2013-0001. McCrank, J. 2009. Nanotechnology applications in the forest sector. Natural Resources Canada, Canadian Forest Service. Ottawa, ON K1A OE4. http://www.cfs.nrcan.gc.ca/pubwarehouse/pdfs/29382.pdf (accessed 30 December 2016)

Min, J.S., K.S. Kim, S.W Kim, J.H. Jung, K. Lamsal, S.B. Kim, M. Jung and Y.S. Lee. 2009. Effects of colloidal silver nanoparticles on sclerotium-forming phytopathogenic fungi. Plant Pathol. J. 25(4):376-380.

Mohanpuria, P., N.K. Rana and S.K. Yadav. 2008. Biosynthesis of nanoparticles: technological concepts and future applications. J. Nanopart. Res. 10: 507-517. doi:10.1007/s11051-010-0145-6.

Monica, C. R. and R. Cremoni 2009. Nanoparticles and higher plants. Caryologia, 62(2): 161-165.

Nel, A., T. Xia, L. Mädler and N. Li. 2006. Toxic potential of materials at the nanolevel. Science, 311: 622-627. doi:10.1126/science.1114397.

Ogar, A., G. Tylko and K. Turnau. 2015. Antifungal properties of silver nanoparticles against indoor mould growth. Sci. Total Environ. 521-522: 305-314. doi: 10.1016/j.scitotenv.2015.03.101.

Qi Y., K. Lian, Q. Wu, Y. Li, M. Danzy, R. Menard, K.L. Chin, D. Collins, F. Oliveria and K. Klepzig. 2012. Potentials of nanotechnology application in forest protection. Proceedings of 2011 TAPPI International Conference on Nanotechnology for Renewable Materials, Washington DC, 6-8 June 2011. pp. 1-5. Curran Associates, Inc. Zarzyński, P. 2003. Ograniczanie rozwoju zgnilizn drewna dębów i lip za pomocą iniekcji fungicydów systemicznych. Limiting the development of oak and linden wood rot by injecting systemic fungicides. Ph.D. Thesis, Department of Forest Protection and Ecology, Warsaw University of Life Sciences, Warsaw, Poland (in Polish).

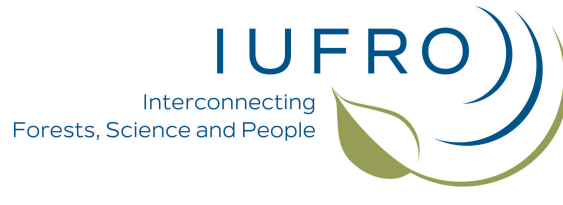

This paper is based on material that was presented at the meeting of IUFRO Working Party 7.02.02 - Foliage, Shoot and Stem Diseases, May 7-11, 2017, Niagara Falls, Ontario, Canada 